\title{
Single-molecule techniques to quantify and genetically characterise persistent HIV
}

Xiao Qian Wang and Sarah Palmer*

\begin{abstract}
Antiretroviral therapy effectively suppresses, but does not eradicate HIV-1 infection. Persistent low-level HIV-1 can still be detected in plasma and cellular reservoirs even after years of effective therapy, and cessation of current treatments invariably results in resumption of viral replication. Efforts to eradicate persistent HIV-1 require a comprehensive examination of the quantity and genetic composition of HIV-1 within the plasma and infected cells located in the peripheral blood and tissues throughout the body. Single-molecule techniques, such as the single-copy assay and single-genome/proviral sequencing assays, have been employed to further our understanding of the source and viral dynamics of persistent HIV-1 during long-term effective therapy. The application of the single-copy assay, which quantifies plasma HIV-1 RNA down to a single copy, has revealed that viremia persists in the plasma and CSF after years of effective therapy. This low-level HIV-1 RNA also persists in the plasma following treatment intensification, treatment with latency reversing agents, cancer-related therapy, and bone marrow transplantation. Single-genome/ proviral sequencing assays genetically characterise HIV-1 populations after passing through different selective pressures related to cell type, tissue type, compartment, or therapy. The application of these assays has revealed that the intracellular HIV-1 reservoir is stable and mainly located in CD4+ memory T cells. Moreover, this intracellular HIV-1 reservoir is primarily maintained by cellular proliferation due to homeostasis and antigenic stimulation, although cryptic replication may take place in anatomic sites where treatment is sub-optimal. The employment of single-genome/ proviral sequencing showed that latency reversing agents broadly activate quiescent proviruses but do not clear the intracellular reservoir. Recently, full-length individual proviral sequencing assays have been developed and the application of these assays has revealed that the majority of intracellular HIV-1 DNA is genetically defective. In addition, the employment of these assays has shown that genetically intact proviruses are unequally distributed in memory $T$ cell subsets during antiretroviral therapy. The application of single-molecule assays has enhanced the understanding of the source and dynamics of persistent HIV-1 in the plasma and cells of HIV-infected individuals. Future studies of the persistent HIV-1 reservoir and new treatment strategies to eradicate persistent virus will benefit from the utilization of these assays.
\end{abstract}

Keywords: Persistent HIV-1, Single-molecule assays, Single-copy assay, Single-genome/proviral sequencing, Full-length individual proviral sequencing, Intracellular HIV-1 reservoirs

\section{Background}

The development of antiretroviral therapy (ART) for the treatment of human immunodeficiency virus (HIV-1) remains one of the great triumphs of modern medicine. However, despite its success, this therapy has a number

\footnotetext{
*Correspondence: sarah.palmer@sydney.edu.au

Centre for Virus Research, The Westmead Institute for Medical Research, The University of Sydney, 176 Hawkesbury Road, Westmead, NSW 2145, Australia
}

of limitations. Effective therapy requires meticulous lifelong adherence, which many HIV-infected patients find challenging. Nearly all treatment regimens are associated with some short-term and long-term toxicity. Moreover, although therapy suppresses viral replication, it does not completely restore health: treated HIV-1 disease is attended by chronic inflammation, persistent $\mathrm{T}$ cell dysfunction, and a shorter life expectancy [1]. In addition, ART is expensive and cannot be delivered sustainably to everyone in need. Finally, and very importantly, since 
HIV-1 DNA persists as an integrated genome in longlived or slowly-dividing cellular reservoirs, current therapeutic approaches are unlikely to prove curative $[2,3]$. In light of these challenges, treatments aimed at HIV-1 eradication stand out as a highly promising avenue to confront and defeat the HIV-1 epidemic $[4,5]$. To move forward down the promising path of HIV-1 eradication strategies, it is critically important to identify where and how reservoirs of HIV-1 persist within HIV-infected individuals on ART and the effects of new curative treatment strategies on these reservoirs.

To measure the level and genetic composition of persistent HIV-1 in plasma, cell and tissue reservoirs, singlemolecule techniques such as the single-copy assay (SCA) and single-genome/proviral sequencing assays (SGS/SPS) have been employed $[6,7]$. SCA has a broad dynamic range $\left(1-10^{6}\right.$ copies $\left./ \mathrm{ml}\right)$ and a limit of detection down to 1 copy of HIV RNA [7]. Using this assay, it was found that approximately $80 \%$ of participants with plasma HIV-1 RNA levels below 50 copies/ $\mathrm{ml}$ had quantifiable viremia $[7,8]$. Notably, this persistent viremia was evident even after seven years of therapy with an overall median HIV-1 RNA level of 3 copies/ml [9] and can result in viral rebound when effective treatment is terminated $[10,11]$. Therefore, monitoring the levels of persistent viremia is not only crucial for confirming the continued effectiveness of ART, but also for determining the effectiveness of new curative treatment strategies for eliminating HIV-1.

Identification of the cells that contribute to the latent HIV-1 reservoir and their maintenance during long-term effective therapy is crucial so that these cells can be targeted for HIV-1 eradication. A well-defined reservoir of HIV-1 is memory CD4 ${ }^{+} \mathrm{T}$ cells, where HIV-1 latency is established when an activated $\mathrm{CD} 4^{+} \mathrm{T}$ cell becomes infected by HIV-1, but transitions to a memory $\mathrm{T}$ cell instead of undergoing lytic infection [2, 12-15]. These memory $\mathrm{T}$ cells contain integrated HIV-1 proviruses and the repression of transcriptional initiation (due to the chromatin environment and recruitment of histone deacetylases) or post-transcriptional blocks (nuclear export, translation) enable HIV-1 to evade detection and clearance by the immune system $[13,16,17]$. The study of viral reservoirs has largely focused on components of peripheral blood, but recent findings suggest that most infected cells are actually found in tissue sites-such as the spleen, lymph nodes and GALT-where $90 \%$ of lymphocytes are located [18-21]. The application of SGS/SPS assays provides a comprehensive understanding of the genetic characteristics and dynamics of persistent HIV-1 across a range of tissues and cells and how new treatments, such as latency reversing agents affect the genetic composition of the intracellular HIV-1 reservoir [22-28].
The amount of replication-competent HIV-1 in activated, resting memory, and memory $\mathrm{T}$ cell subsets or the actual size of the latent HIV-1 reservoir, during effective antiretroviral therapy is unclear [29]. The estimate of latently infected cells is 1 replication-competent provirus per 1 million resting memory CD4+ T cells [2, 30, 31]. However, as recently described by Ho and colleagues, the number of replication-competent proviruses in these cells is underestimated and could be 60 -fold higher than previously predicted [32]. The design of future HIV-1 curative therapies require a more thorough understanding of the distribution of replication-competent HIV-1, i.e. the latent reservoir, within $T$ cell subsets. The employment of recently developed full-length individual proviral sequencing assays will assist with the identification of the precise cellular location and amount of genetically intact virus that should be targeted by new curative therapies [32-35].

This review will discuss how the application of singlemolecule techniques have enhanced our understanding of the level, location, and cellular mechanisms contributing to persistent HIV-1 in the plasma, cells and tissues of HIV-1-infected individuals on effective therapy. In addition, this review will describe how these technologies have been applied to investigate the effectiveness of curative strategies.

\section{Quantification of persistent HIV-1 RNA using the single-copy assay}

In 2003, the original single-copy assay (SCA) was developed to quantify the levels of persistent viremia in the plasma of participants on effective therapy [7]. This assay uses larger plasma sample volumes $(7 \mathrm{ml})$, improved nucleic acid isolation and purification techniques, and RT-PCR to accurately quantify HIV-1 in plasma samples over a broad dynamic range $\left(1-10^{6}\right.$ copies $\left./ \mathrm{ml}\right)$. The limit of detection down to 1 copy of HIV-1 RNA makes SCA 20-50 times more sensitive than currently approved commercial assays. To control for recovery of HIV1 , each plasma sample is spiked with an internal virion standard derived from an unrelated retrovirus, the replication competent avian sarcoma-leukosis retrovirus vector RCAS BP(A). The employment of SCA revealed that approximately $80 \%$ of participants with plasma HIV-1 RNA levels below 50 copies $/ \mathrm{ml}$ had quantifiable viremia $[7,8]$. This persistent viremia was evident in a study of 40 participants even after 7 years of therapy with an overall median HIV-1 RNA level of 3 copies/ml [9]. The level of viremia correlated with pre-therapy plasma HIV-1 RNA, but not with the specific treatment regimen. A nonlinear mixed effects model revealed a biphasic decline in plasma RNA levels occurring over weeks 60-384: an initial phase 
of decay with a half-life of 39 weeks and a subsequent phase with no perceptible decay. These data suggest there is a continual cellular source of persistent virus which contributes to viral rebound if ART is terminated.

Low-level viremia has been detected in the plasma of elite controllers; HIV-infected individuals who maintain plasma HIV-1 RNA levels $<50$ copies/mL in the absence of any treatment [36-38]. Quantification of paired plasma and cerebrospinal fluid (CSF) samples from elite controllers revealed that significantly fewer CSF samples had detectable HIV-1 RNA compared to plasma samples 19 and 54\% respectively $(p=0.02)$ [36]. Studies that measured HIV-1 RNA levels in paired plasma and CSF samples from ART-suppressed HIV-infected participants using SCA revealed that the proportion of samples with measurable HIV-1 RNA was lower in CSF samples (14-17\%) compared to plasma samples (57-64\%) and the median levels of HIV-1 RNA in the CSF were significantly lower ( $\mathrm{p} \leq 0.0001$ ) [39]. HIV-1 RNA was quantified in the CSF even after 10 years of effective therapy and correlated to elevated levels of CSF neopterin, a marker for intrathecal immune activation. To date, it is unknown whether the infrequent and lower amounts of HIV-1 RNA in the CSF of participants on effective therapy reflect viral production within the CNS where ART levels can be lower or virion exchange between CSF and the blood.

Studies of persistent virus using a modified SCA have found that plasma viremia decays slowly with time [40, 41]. In a recent study, molecular beacon technology with single-copy detection was used to quantify HIV-1 RNA in plasma and CSF of participants on effective ART experiencing neurocognitive disorders [42]. These studies revealed that $42 \%$ of CSF samples from 220 HIV-positive individuals contained HIV-1 RNA persisting for over 7 months in $69 \%$ of these participants. This low-level HIV-1 RNA in the CSF correlated with persistent viremia in the plasma and lower concentrations and distribution of ART into the CNS. However, poor neurocognitive performance was associated with lower HIV-1 RNA levels in the CSF and discordance between HIV-1 RNA levels between the CSF and plasma.

\section{The effects of treatment intensification on persistent viremia}

In addition to the persistence of long-lived latently infected cells, low-level viral replication has been proposed as a mechanism that maintains HIV-1 during longterm effective therapy [43, 44]. If on-going replication is contributing to persistent viremia, treatment intensification, the addition of one or more compounds to existing ART, should reduce this residual viremia. However, treatment intensification-for example, the addition of another drug such as raltegravir, to existing ART or treating participants with an intensified therapy of 5 versus 3 drugs- has shown no perceptible change in persistent viremia in individuals receiving the intensified treatment, which suggests that on-going viral replication is not a probable source of persistent viremia [45-49]. In contrast, some studies of treatment intensification revealed that patients had an increase in episomal (unintegrated) HIV-1 DNA and decreased amounts of unspliced HIV-1 RNA in $\mathrm{CD}^{+}{ }^{+}$T-cells isolated from the terminal ileum $[50,51]$. The results of these latter studies support the concept that some viral replication can occur despite suppressive HIV-1 therapy.

\section{The effects of latency reversing agents and cancer-related therapies on persistent viremia}

HIV-1 latency is established when an activated $\mathrm{CD} 4^{+}$ $\mathrm{T}$ cell becomes infected by HIV-1 but transitions to a memory $\mathrm{T}$ cell carrying an integrated HIV-1 provirus that is transcriptionally silent, thus evading detection and clearance by the immune system $[2,12,14,15]$. Current research is focused on developing interventions such as latency reversing agents which involve the use of small molecules approved for cancer therapy, including histone deacetylase inhibitors (HDACis), to induce viral transcription in latently infected cells followed by immune mediated clearance of these virus-producing cells [52-55]. The administration of HDACis, including panobinostat, vorinostat, and romidepsin, to HIV-infected persons on effective ART enhanced intracellular HIV transcription and significantly increased cell-associated HIV-1 RNA (CA HIV-1 RNA) consistent with reversing latency [53-55]. In addition, treatment with panobinostat and romidepsin also increased plasma HIV-1 RNA levels, whereas no effect on plasma HIV-1 RNA levels was found during single-dose or multi-dose vorinostat therapy [52-55]. In 2011, disulfiram [bis(diethylthiocarbamoyl) disulfide], a compound used to treat alcoholism, was found to reactivate latent HIV-1 in a cell-based screen [56]. Clinical trials were established to treat HIV-infected individuals on effective ART with multi-dose disulfiram. The administration of disulfiram transiently increased plasma HIV-1 RNA levels in a subset of participants [57, 58], but there was no demonstrable effect on the size of the intracellular latent HIV-1 reservoir after treatment with HDACis or disulfiram.

Additional compounds being developed for treating cancer are being investigated as potential therapies to reduce persistent HIV-1 [59]. The upregulation of immune checkpoint coreceptors, such as programmed death 1 (PD-1) and cytotoxic T-lymphocyte associated protein 4 (CTLA-4), on malignant cells allows them to avoid immune destruction. Antibodies directed against 
PD-1, CTLA-4 and a ligand of PD-1 called PD-L1 or immune checkpoint inhibitors are being used effectively in cancer immunotherapy to enhance antitumor responses. Due to chronic HIV-1 antigenic stimulation, immune checkpoint coreceptors are upregulated on CD4+ and CD8+ $\mathrm{T}$ cells of HIV-1-infected individuals, resulting in $\mathrm{T}$ exhaustion and disease progression $[60,61]$. Moreover, cells expressing PD-1 are enriched for integrated HIV-1 DNA in the blood and lymph node indicating that PD-1 expressing cells play a role in HIV-1 persistence [60]. The treatment of six HIV-infected individuals on effective ART with an antibody to the PD-1 ligand, anti-PD-L1, enhanced HIV-1 specific T cells but did not affect the levels of persistent viremia [62]. However, the treatment of an HIV-infected individual on ART with melanoma with anti-CTLA-4 (ipilimumab) resulted in an increase in cell-associated HIV-1 RNA and a cyclical decrease in plasma HIV-1 RNA following each treatment with an overall decline from 60 to 5 copies/ml [63]. Cancer-related therapies are being explored for their capacity to enhance latency reversal or promote killing of virus producing cells and several new therapies are in clinical trials [64].

\section{Memory T cells contain one HIV-1 DNA molecule}

Efforts to eradicate HIV-1 require a comprehensive examination of the quantity and genetic composition of HIV-1 within infected cells located in cells and tissues throughout the body. To determine the relationship among proviruses in cells from peripheral blood and tissue compartments, a single-cell sequencing technique was developed which allowed for the examination of individual viral DNA molecules from single cells. The quantification of viral DNA molecules per infected cell and the relatedness of viral DNA sequences to one another, to DNA in other cells, and to contemporaneous plasma virus RNA can also be determined. The application of the single-cell sequencing assay to cells from untreated HIVinfected participants revealed a correlation between viral RNA levels and frequency of intracellular HIV-1 DNA infection [23]. When analyzing the degree of multiple infection of $\mathrm{CD} 4^{+} \mathrm{T}$-cells in peripheral blood and lymph node tissue it was found that the vast majority $(>90 \%)$ of the CD4+ T cells from peripheral blood and lymph node tissue contained only one HIV-1 DNA molecule, implying a limited potential for recombination in virus produced by these cells [23]. This result is in contrast to the generally accepted belief that most HIV-infected cells contain multiple HIV DNA molecules $[65,66]$. These studies demonstrated a similar genetic composition of HIV-1 in lymph node tissue, peripheral blood cells and plasma of untreated participants [24]. This finding implies ongoing exchange between these compartments during untreated HIV-1 infection. In these single-cell studies not one HIV-1-infected monocyte was identified indicating that monocytes are not a major reservoir within HIV-1 infected untreated individuals.

\section{Genetic characterisation of persistent virus in plasma and cells}

To determine the source of persistent viremia and the effects of treatment initiation on the latent HIV-1 reservoir, the genetic composition of persistent virus in the plasma and cells from patients on long-term effective therapy must be assessed. In a seminal study of memory $\mathrm{T}$ cell subsets, Chomont et al. found integrated HIV-1 DNA in central memory $\mathrm{T}$ cells $\left(\mathrm{T}_{\mathrm{CM}}\right)$ and transitional memory $\mathrm{T}$ cells $\left(\mathrm{T}_{\mathrm{TM}}\right)$. They found that the low proliferation rate of $\mathrm{T}_{\mathrm{CM}}$ allows them to persist in HIV-1-infected participants with relatively high $\mathrm{CD} 4+\mathrm{T}$ cell counts. In participants with low $\mathrm{CD} 4+$ counts, $\mathrm{T}_{\mathrm{TM}}$ cells appear to be the major reservoir, which is maintained by IL-7 induced homeostatic proliferation and plasma levels of IL-7 correlated inversely to the rate of decrease of the reservoir. This study suggests that there are at least two cellular mechanisms by which the reservoir within HIV1-infected memory CD4+ T-cells is maintained [12].

The study of viral reservoirs has largely focused on components of peripheral blood. However, recent findings suggest that most infected cells are actually found in tissue sites-such as the spleen, lymph nodes and GALT-where $90 \%$ of lymphocytes are located [18-21, $67,68]$. Therefore, a more comprehensive understanding of the genetic characteristics and dynamics of persistent HIV-1 across a range of tissues and cells is necessary. Single-genome/proviral sequencing (SGS/SPS) has been applied to assess the genetic composition of plasmaderived HIV-1 RNA, cell-associated (CA) HIV-1 RNA and HIV-1 DNA. In conducting these assays, HIV-1 RNA is extracted from plasma and CA HIV-1 RNA and DNA is extracted from cells derived from peripheral blood, gut-associated lymphoid tissue (GALT), lymph nodes, and bone marrow [20-23, 25, 67] and subsequently sequenced at limiting dilution to assess genetic diversity, genetic evolution, and infection frequency [22-25, 27, 69]. Genetic characterisation of HIV-1 DNA extracted from memory $\mathrm{T}$ cell subsets including TCM, TTM, effector memory T cells (TEM), and myeloid cells from peripheral blood, GALT, and lymph nodes, from ART-suppressed participants strongly suggests that the primary barrier to a cure is the remarkably stable pool of memory $\mathrm{T}$ cells. In agreement with earlier studies, SGS/ SPS analyses revealed that naive T cells contain HIV-1, albeit at a lower infection frequency compared to memory $\mathrm{T}$ cell subsets [70-72]. These studies also revealed that participants treated during acute infection had 
genetically homogeneous HIV-1 populations in all cells from all anatomic compartments and substantially lower HIV-1 reservoir size in blood, gut, and lymph node.

A study by Carter et al. [73] has shown that HIV-1 infects multipotent hematopoietic progenitor cells (HPCs) and that latent HIV-1 infection was established in some of these HPCs, although further research was needed to test whether persistent virus in memory $\mathrm{T}$ cells in participants on effective therapy was partially derived from HPCs. Recent studies of HPCs (Lin-CD34-) sorted from bone marrow revealed that these cells do not appear to contain HIV-1 and if this cellular population is infected, the frequency of infection is very low $(<0.0005 \%)$ [22, 74]. In addition, studies attempted to investigate the infection frequency of myeloid cells using SGS/SPS, but there was a high likelihood that the sorted myeloid cell population was contaminated with $\mathrm{T}$ cells, which still leaves the role of myeloid cells in the persistence of HIV-1 an open question [25, 27]. However, the overall low HIV-1 infection frequency of myeloid cells indicates that if myeloid cells from peripheral blood, GALT and lymph node are infected, their importance as a latent HIV-1 reservoir in participants on ART may be limited.

Finally, applying these sensitive SGS/SPS techniques to compare the genetic composition of intracellular HIV-1 populations to pre-ART plasma extracellular viral RNA showed very low levels of genetic change during longterm effective therapy. In fact, one study estimated that the evolutionary rate was no greater than 0.0006 and 0.002 nucleotide substitutions/site during the 4-12 years of suppressive therapy for the participants treated during early and chronic infection, respectively [25]. These results suggest viral replication is not a major cause of persistence in the cellular populations analysed and that persistent intracellular HIV-1 DNA is most likely maintained by homeostatic and/or antigen-specific cellular proliferation [12, 25-27].

\section{Anti-latency compounds broadly activate latent HIV-1 proviruses}

A promising HIV-1 curative strategy called "shock and kill" involves treating patients on effective antiretroviral therapy with anti-latency compounds, such as histone deacetylase inhibitors (HDACIs), which enhance HIV-1 transcription and reactivate or "shock" provirus from latent reservoirs [52-55]. The administration of the HDACIs, panobinostat, vorinostat, and romidepsin to HIV-1 infected individuals on antiretroviral therapy induces a significant increase in CA HIV-1 RNA from CD4+ T cells [53-55]. However, it is important to discern whether the increases in CA HIV-1 RNA are due to activation of a subset of proviruses or to global non-selective activation of a broad spectrum of latent proviruses. SGS/ SPS analyses of CA HIV-1 RNA and DNA and plasmaderived RNA showed that the transcriptomes following panobinostat, vorinostat, and romidepsin administration are genetically diverse and intermingle on phylogenetic trees with intracellular HIV-1 DNA, indicating activation of transcription from an extensive range of integrated latent proviruses [69, 75]. HIV-1 sequences from blood $\mathrm{CD} 4+\mathrm{T}$ cells and intestinal lamina propria mononuclear cells (LPMCs) of ART-suppressed individuals during and after treatment with panobinostat or romidepsin were compared to sequences from analytical treatment interruption (ATI) plasma after all therapy was stopped. These studies identified CA HIV-1 RNA and DNA sequences in the blood and LPMCs collected during panobinostat or romidepsin treatment that were closely related or identical to plasma sequences from the ATI $[69,75]$. This demonstrates that both the intestines and blood are important reservoirs of HIV-1 during effective therapy and that these anatomic sites can harbour HIV-1 capable of emerging during a treatment interruption.

\section{Full-length individual proviral sequencing to identify the latent HIV-1 reservoir}

The design of future HIV-1 curative therapies require a more thorough understanding of the distribution of replication-competent HIV-1, i.e. the latent reservoir, within T cell subsets. Even though SGS/SPS can provide an in-depth genetic analysis and infection frequency of HIV-1 within specific $T$ cell subsets, these assays overestimate the amount of replication-competent virus which resides within cells (Fig. 1) [34]. Therefore, full-length HIV sequencing of $>90 \%$ of the HIV genome has been developed by several research groups [32-35]. The initial full-length HIV-1 assay involved the amplification of four overlapping segments of a single HIV-1 genome which were then sequenced and consolidated into one genome [32]. This assay allowed for the identification of defective versus intact HIV-1 genomes and studies with this method revealed that the latent HIV-1 reservoir was underestimated by earlier in vitro assays [32]. Recently two research groups have developed assays utilizing next generation sequencing to amplify and sequence single near full-length HIV-1 proviruses within CD4+ T cell subsets [34, 35], which allows for in-depth genome-scale analyses of the HIV-1 populations in cells sorted from the peripheral blood and anatomic tissue sites. The application of full-length individual proviral sequencing reveals that intact proviruses which potentially contribute to viral rebound following a treatment interruption were unequally distributed across $\mathrm{T}$ cell subsets. In addition, the presence of identical sequence expansions of intact proviruses indicates that proliferating cells contain virus 


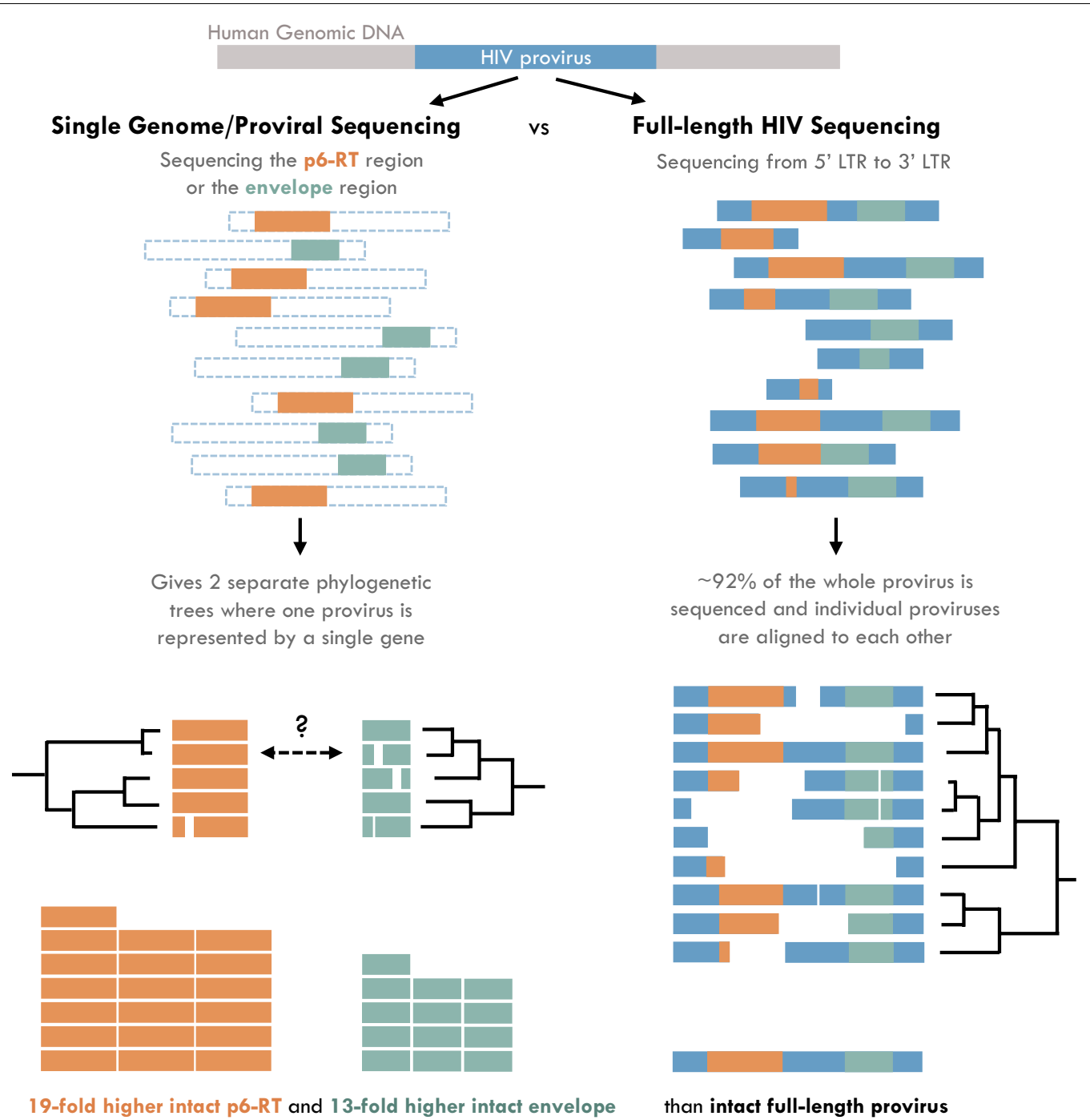

Fig. 1 Single-genome/proviral sequencing overestimates the amount of replication-competent proviruses. p6-RT region shown in orange and $\mathrm{V} 1-\mathrm{V} 3$ env region shown in green

capable of rebound and actively contribute to the latent reservoir.

\section{Alternative methods for measuring persistent HIV-1}

Several methods for measuring persistent HIV-1 have been developed, and these assays identify replicationcompetent proviruses to varying degrees of sensitivity and specificity (Table 1). These can be categorised into cell culture based assays and PCR-based assays.

\section{Cell culture based assays}

The principal assay for estimating the amount of replication-competent provirus in resting memory $\mathrm{T}$ cells is the Quantitative Viral Outgrowth Assay (QVOA). In performing this assay resting memory CD4+ $\mathrm{T}$ cells are cultured at limiting dilution and stimulated with a $\mathrm{T}$ cell mitogen, such as phytohemagglutinin (PHA), to activate the transcription of the proviruses within these cells [76]. These activated cells are co-cultured with HIV-1 negative donor $\mathrm{CD} 4^{+} \mathrm{T}$ cells and virions released into the supernatant are then quantified by real-time quantitative PCR or enzyme-linked immunosorbent assay. However, recent studies have shown that not all replication-competent virus is induced by this method and that the QVOA underestimates the HIV-1 latent reservoir by as much as 60-fold [31]. Another assay, the Tat/Rev Induced Limiting Dilution Assay (TILDA) also involves stimulation of enriched CD4+ $\mathrm{T}$ cells with PHA and ionomycin to induce provirus 


\begin{tabular}{|c|c|c|c|}
\hline Assay name & $\begin{array}{l}\text { PCR or cell culture } \\
\text { based }\end{array}$ & Strengths of the assay & Weaknesses of the assay \\
\hline $\begin{array}{l}\text { Quantification of HIV-1 RNA in } \\
\text { plasma and CSF }\end{array}$ & PCR & Fast and high throughput & $\begin{array}{l}\text { The low levels of viremia in participants on long- } \\
\text { term ART could affect accuracy of this assay. } \\
\text { Not a true representation of the intracellular } \\
\text { reservoir }\end{array}$ \\
\hline $\begin{array}{l}\text { Quantification of intracellular HIV-1 } \\
\text { RNA and DNA }\end{array}$ & PCR & Fast and high throughput & $\begin{array}{l}\text { Overestimates the size of the reservoir. Does not } \\
\text { provide an indication of replication compe- } \\
\text { tency }\end{array}$ \\
\hline Single-genome sequencing & PCR & High throughput & $\begin{array}{l}\text { Overestimates the size of the reservoir. Does not } \\
\text { provide an indication of replication compe- } \\
\text { tency }\end{array}$ \\
\hline $\begin{array}{l}\text { Full-length individual proviral } \\
\text { sequencing }\end{array}$ & PCR & Relatively high throughput & $\begin{array}{l}\text { Expensive technique. Slightly overestimates the } \\
\text { size of the reservoir. Replication competency of } \\
\text { genetically intact proviruses will require confir- } \\
\text { mation by in vitro assays }\end{array}$ \\
\hline Quantitative viral outgrowth assay & Cell culture & $\begin{array}{l}\text { Quantifies replication-competent } \\
\text { virus }\end{array}$ & $\begin{array}{l}\text { Requires large numbers of resting memory T cells } \\
\text { and is labour-intensive. Underestimates the size } \\
\text { of the reservoir due to non-induced proviruses }\end{array}$ \\
\hline $\begin{array}{l}\text { Tat/rev induced limiting dilution } \\
\text { assay }\end{array}$ & Cell culture & $\begin{array}{l}\text { Gives an indication of the size of the } \\
\text { inducible reservoir }\end{array}$ & $\begin{array}{l}\text { Requires sizeable numbers of cells and cannot be } \\
\text { used for sorted T cell subsets. Overestimates the } \\
\text { size of the reservoir }\end{array}$ \\
\hline
\end{tabular}

expression. These cells are serially diluted, subjected to a pre-amplification RT-PCR step, and then quantified by real-time quantitative PCR using primers and probes specific for the tat/rev region [77]. As such, this assay measures the frequency of inducible multiplyspliced HIV-1 RNA in latently-infected cells. Although this assay is more sensitive in detecting the functional HIV-1 reservoir than PCR-based assays (described below), some cells that generate a positive TILDA signal will not produce infectious virions and this can lead to an overestimation of the latent and replication-competent HIV-1 reservoir.

\section{PCR-based assays}

Due to the laborious nature of cell culture assays, as well as the large volumes of sample required, PCR-based assays have been employed as a high-throughput alternative for the quantification of intracellular HIV RNA and DNA [12, 78-80]. These assays amplify intracellular HIV RNA and DNA which is then quantified by real-time PCR or digital droplet PCR techniques [81-83]. However, these PCR-based assays overestimate the size of the viral reservoir as they typically quantify a portion of the HIV genome, such as the LTR region, which gives no indication as to whether the virus is replication competent. The virus could be defective outside of the genomic region which is quantified by these assays.

Single-genome sequencing of a specific viral genomic region provides some insight into the replication competency of a particular provirus, but many proviruses have large internal deletions or defects in genes outside of the sequenced region that will not be detected by this method [34]. Full-length individual proviral sequencing provides a stringent approach to identifying genetically intact HIV-1 proviruses without requiring these proviruses to be reactivated. However, it would require in vitro studies to confirm that the genetically intact proviruses identified by this method are truly replication competent.

\section{Conclusion}

Single-molecule techniques, such as the single-copy assay and single-genome/proviral sequencing assays, have been employed to investigate the source and viral dynamics of persistent HIV-1 during long-term effective therapy. These assays have been employed to determine the effectiveness of new therapeutic treatments in reducing viremia and activating latent virus. Although great strides have been made with these techniques, there are many aspects of HIV-1 persistence that have yet to be explored, such as whether there is on-going replication in anatomic sites where treatment is sub-optimal [84]. Moreover, additional studies are required to fully determine all the cells and anatomic sites where genetically intact replication-competent virus resides.

Looking ahead, the full-length individual proviral sequencing assay holds particular promise to help answer these and other questions concerning the source and dynamics of replication-competent virus. In particular, 
this assay should be widely applied to interrogate cells from anatomical sites, such as the spleen, liver and central nervous system. This current full-length proviral sequencing assay will need to be complemented with a newly developed full-length HIV-1 RNA sequencing assay in order to provide the fullest possible picture of the latent HIV reservoir and the effects of new curative treatment strategies.

\begin{abstract}
Abbreviations
ART: antiretroviral therapy; HIV-1: human immunodeficiency virus; SCA: single-copy assay; SGS/SPS: single-genome/proviral sequencing assays; CSF: cerebrospinal fluid; HDACis: histone deacetylase inhibitors; Disulfiram: (bis(diethylthiocarbamoyl)disulfide); PD-1: programmed death 1; CTLA-4: cytotoxic T-lymphocyte associated protein 4; TCM: central memory T cells; TTM: transitional memory T cells; CA: cell-associated; GALT: gut-associated lymphoid tissue; TEM: effector memory T cells; HPCs: hematopoietic progenitor cells; LPMCs: intestinal lamina propria mononuclear cells; ATI: analytical treatment interruption; PHA: phytohemagglutinin.
\end{abstract}

\section{Authors' contributions}

XQW and SP wrote the manuscript and made the figure. Both authors read and approved the final manuscript.

\section{Acknowledgements}

This work was supported the Delaney AIDS Research Enterprise (DARE) to Find a Cure (1U19AI096109 and 1UM1Al126611-01), an amfAR Research Consortium on HIV Eradication (ARCHE) Collaborative Research Grant from The Foundation for AIDS Research (amfAR 108074-50-RGRL), Australian Centre for HIV and Hepatitis Virology Research (ACH2), and the Australian National Health and Medical Research Council (AAP1061681).

\section{Competing interests}

The authors declare that they have no competing interests.

\section{Availability of data and materials}

Not applicable.

\section{Consent for publication}

Not applicable.

\section{Ethics approval and consent to participate}

Not applicable.

\section{Publisher's Note}

Springer Nature remains neutral with regard to jurisdictional claims in published maps and institutional affiliations.

Received: 11 October 2017 Accepted: 23 December 2017

Published online: 09 January 2018

\section{References}

1. Deeks SG. HIV infection, inflammation, immunosenescence, and aging. Annu Rev Med. 2011;62:141-55.

2. Finzi D, Hermankova M, Pierson T, Carruth LM, Buck C, Chaisson RE, Quinn TC, Chadwick K, Margolick J, Brookmeyer R, et al. Identification of a reservoir for HIV-1 in patients on highly active antiretroviral therapy. Science. 1997;278(5341):1295-300.

3. Siliciano JD, Siliciano RF. A long-term latent reservoir for HIV-1: discovery and clinical implications. J Antimicrob Chemother. 2004;54(1):6-9.
4. Deeks SG, Autran B, Berkhout B, Benkirane M, Cairns S, Chomont N, Chun TW, Churchill M, Di Mascio M, Katlama C, et al. Towards an HIV cure: a global scientific strategy. Nat Rev Immunol. 2012;12(8):607-14.

5. Deeks SG, Lewin SR, Ross AL, Ananworanich J, Benkirane M, Cannon P, Chomont N, Douek D, Lifson JD, Lo YR, et al. International AIDS Society global scientific strategy: towards an HIV cure 2016. Nat Med. 2016;22(8):839-50.

6. Palmer S, Kearney M, Maldarelli F, Halvas EK, Bixby CJ, Bazmi H, Rock D, Falloon J, Davey RT Jr, Dewar RL, et al. Multiple, linked human immunodeficiency virus type 1 drug resistance mutations in treatment-experienced patients are missed by standard genotype analysis. J Clin Microbiol. 2005;43(1):406-13.

7. Palmer S, Wiegand AP, Maldarelli F, Bazmi H, Mican JM, Polis M, Dewar RL, Planta A, Liu S, Metcalf JA, et al. New real-time reverse transcriptase-initiated PCR assay with single-copy sensitivity for human immunodeficiency virus type 1 RNA in plasma. J Clin Microbiol. 2003;41(10):4531-6.

8. Maldarelli F, Palmer S, King MS, Wiegand A, Polis MA, Mican J, Kovacs JA, Davey RT, Rock-Kress D, Dewar R, et al. ART suppresses plasma HIV-1 RNA to a stable set point predicted by pretherapy viremia. PLoS Pathog. 2007:3(4):e46.

9. Palmer S, Maldarelli F, Wiegand A, Bernstein BM, Hanna GJ, Brun SC, Kempf DJ, Mellors JW, Coffin JM, King M. Low-level viremia persists for at least 7 years in patients on suppressive antiretroviral therapy. PNAS 2008;105(10):3879-84.

10. Doyle T, Smith C, Vitiello P, Cambiano V, Johnson M, Owen A, Phillips AN, Geretti AM. Plasma HIV-1 RNA detection below 50 copies $/ \mathrm{ml}$ and risk of virologic rebound in patients receiving highly active antiretroviral therapy. Clin Infect Dis. 2012;54(5):724-32.

11. Maggiolo F, Callegaro A, Cologni G, Bernardini C, Velenti D, Gregis G, Quinzan G, Soavi L, lannotti N, Malfatto E, et al. Ultrasensitive assessment of residual low-level HIV viremia in HAART-treated patients and risk of virological failure. J Acquir Immune Defic Syndr. 2012;60(5):473-82.

12. Chomont N, El-Far M, Ancuta P, Trautmann L, Procopio FA, Yassine-Diab B, Boucher G, Boulassel MR, Ghattas G, Brenchley JM, et al. HIV reservoir size and persistence are driven by $T$ cell survival and homeostatic proliferation. Nat Med. 2009;15(8):893-900.

13. Palmer S, Josefsson L, Coffin JM. HIV reservoirs and the possibility of a cure for HIV infection. J Intern Med. 2011;270(6):550-60.

14. Siliciano JD, Kajdas J, Finzi D, Quinn TC, Chadwick K, Margolick JB, Kovacs C, Gange SJ, Siliciano RF. Long-term follow-up studies confirm the stability of the latent reservoir for HIV-1 in resting CD4+ T cells. Nat Med. 2003;9(6):727-8.

15. Siliciano JD, Lai J, Callender M, Pitt E, Zhang H, Margolick JB, Gallant JE, Cofrancesco J Jr, Moore RD, Gange SJ, et al. Stability of the latent reservoir for HIV-1 in patients receiving val proic acid. J Infect Dis. 2007:195(6):833-6.

16. Williams SA, Chen LF, Kwon H, Ruiz-Jarabo CM, Verdin E, Greene WC. NF-kappaB p50 promotes HIV latency through HDAC recruitment and repression of transcriptional initiation. EMBO J. 2006;25(1):139-49.

17. Mbonye $U$, Karn J. The molecular basis for human immunodeficiency virus latency. Annu Rev Virol. 2017;4(1):261-85.

18. Chun TW, Nickle DC, Justement JS, Meyers JH, Roby G, Hallahan CW, Kottilil S, Moir S, Mican JM, Mullins JI, et al. Persistence of HIV in gut-associated lymphoid tissue despite long-term antiretroviral therapy. J Infect Dis. 2008;197(5):714-20.

19. Gunthard HF, Havlir DV, Fiscus S, Zhang ZQ, Eron J, Mellors J, Gulick R, Frost SD, Brown AJ, SchleifW, et al. Residual human immunodeficiency virus (HIV) Type 1 RNA and DNA in lymph nodes and HIV RNA in genital secretions and in cerebrospinal fluid after suppression of viremia for 2 years. J Infect Dis. 2001;183(9):1318-27.

20. Pantaleo G, Graziosi C, Fauci AS. New concepts in the immunopathogenesis of human immunodeficiency virus infection. N Engl J Med. 1993;328(5):327-35.

21. Veazey RS, Lackner AA. The gastrointestinal tract and the pathogenesis of AIDS. AIDS. 1998;12(Suppl A):S35-42.

22. Josefsson L, Eriksson S, Sinclair E, Ho T, Killian M, Epling L, Shao W, Lewis B, Bacchetti P, Loeb L, et al. Hematopoietic precursor cells isolated from patients on long-term suppressive HIV therapy did not contain HIV-1 DNA. J Infect Dis. 2012;206(1):28-34. 
23. Josefsson L, King MS, Makitalo B, Brannstrom J, Shao W, Maldarelli F, Kearney MF, Hu WS, Chen J, Gaines H, et al. Majority of CD4+ T cells from peripheral blood of HIV-1-infected individuals contain only one HIV DNA molecule. Proc Natl Acad Sci USA. 2011;108(27):11199-204.

24. Josefsson L, Palmer S, Faria NR, Lemey P, Casazza J, Ambrozak D, Kearney M, Shao W, Kottilil S, Sneller M, et al. Single cell analysis of lymph node tissue from HIV-1 infected patients reveals that the majority of CD4+ T-cells contain one HIV-1 DNA molecule. PLoS Pathog. 2013;9(6):e1003432.

25. Josefsson L, von Stockenstrom S, Faria NR, Sinclair E, Bacchetti P, Killian M, Epling L, Tan A, Ho T, Lemey P, et al. The HIV-1 reservoir in eight patients on long-term suppressive antiretroviral therapy is stable with few genetic changes over time. Proc Natl Acad Sci USA. 2013;110(51):E4987-96.

26. Kearney MF, Spindler J, Shao W, Yu S, Anderson EM, O'Shea A, Rehm C, Poethke C, Kovacs N, Mellors JW, et al. Lack of detectable HIV-1 molecular evolution during suppressive antiretroviral therapy. PLoS Pathog. 2014;10(3):e1004010.

27. von Stockenstrom S, Odevall L, Lee E, Sinclair E, Bacchetti P, Killian M, Epling L, Shao W, Hoh R, Ho T, et al. Longitudinal genetic characterization reveals that cell proliferation maintains a persistent HIV type 1 DNA pool during effective HIV therapy. J Infect Dis. 2015;212(4):596-607.

28. Wiegand A, Spindler J, Hong FF, Shao W, Cyktor JC, Cillo AR, Halvas EK, Coffin JM, Mellors JW, Kearney MF. Single-cell analysis of HIV-1 transcriptional activity reveals expression of proviruses in expanded clones during ART. Proc Natl Acad Sci USA. 2017;114(18):E3659-68.

29. Eriksson S, Graf EH, DahI V, Strain MC, YukI SA, Lysenko ES, Bosch RJ, Lai J, Chioma S, Emad F, et al. Comparative analysis of measures of viral reservoirs in HIV-1 eradication studies. PLoS Pathog. 2013;9(2):e1003174.

30. Chun TW, Carruth L, Finzi D, Shen X, DiGiuseppe JA, Taylor H, Hermankova M, Chadwick K, Margolick J, Quinn TC, et al. Quantification of latent tissue reservoirs and total body viral load in HIV-1 infection. Nature. 1997;387(6629):183-8.

31. Chun TW, Stuyver L, Mizell SB, Ehler LA, Mican JA, Baseler M, Lloyd AL, Nowak MA, Fauci AS. Presence of an inducible HIV-1 latent reservoir during highly active antiretroviral therapy. Proc Natl Acad Sci USA. 1997;94(24):13193-7.

32. Ho YC, Shan L, Hosmane NN, Wang J, Laskey SB, Rosenbloom DI, Lai J, Blankson JN, Siliciano JD, Siliciano RF. Replication-competent noninduced proviruses in the latent reservoir increase barrier to HIV-1 cure. Cell. 2013;155(3):540-51.

33. Bruner KM, Murray AJ, Pollack RA, Soliman MG, Laskey SB, Capoferri AA, Lai J, Strain MC, Lada SM, Hoh R, et al. Defective proviruses rapidly accumulate during acute HIV-1 infection. Nat Med. 2016;22(9):1043-9.

34. Hiener B, Horsburgh BA, Eden JS, Barton K, Schlub TE, Lee E, von Stockenstrom S, Odevall L, Milush JM, Liegler T, et al. Identification of genetically intact HIV-1 proviruses in specific CD4+ T cells from effectively treated participants. Cell Rep. 2017;21(3):813-22.

35. Lee GQ, Orlova-Fink N, Einkauf K, Chowdhury FZ, Sun X, Harrington S, Kuo HH, Hua S, Chen HR, Ouyang Z, et al. Clonal expansion of genomeintact HIV-1 in functionally polarized Th1 CD4+ T cells. J Clin Investig. 2017;127(7):2689-96.

36. Dahl V, Peterson J, Spudich S, Lee E, Shacklett BL, Price RW, Palmer S. Single-copy assay quantification of HIV-1 RNA in paired cerebrospinal fluid and plasma samples from elite controllers. AIDS. 2013;27(7):1145-9.

37. Hatano H, Yukl SA, Ferre AL, Graf EH, Somsouk M, Sinclair E, AbdelMohsen M, Liegler T, Harvill K, Hoh R, et al. Prospective antiretroviral treatment of asymptomatic, HIV-1 infected controllers. PLoS Pathog. 2013;9(10):e1003691.

38. Pereyra F, Palmer S, Miura T, Block BL, Wiegand A, Rothchild AC, Baker B, Rosenberg $\mathrm{R}$, Cutrell $\mathrm{E}$, Seaman MS, et al. Persistent low-level viremia in HIV-1 elite controllers and relationship to immunologic parameters. J Infect Dis. 2009;200(6):984-90.

39. Dahl V, Peterson J, Fuchs D, Gisslen M, Palmer S, Price RW. Low levels of HIV-1 RNA detected in the cerebrospinal fluid after up to 10 years of suppressive therapy are associated with local immune activation. AIDS. 2014;28(15):2251-8

40. Cillo AR, Vagratian D, Bedison MA, Anderson EM, Kearney MF, Fyne E, Koontz D, Coffin JM, Piatak M Jr, Mellors JW. Improved single-copy assays for quantification of persistent HIV-1 viremia in patients on suppressive antiretroviral therapy. J Clin Microbiol. 2014;52(11):3944-51.

41. Riddler SA, Aga E, Bosch RJ, Bastow B, Bedison M, Vagratian D, Vaida F, Eron JJ, Gandhi RT, Mellors JW. Continued slow decay of the residual plasma viremia level in HIV-1-infected adults receiving long-term antiretroviral therapy. J Infect Dis. 2016;213(4):556-60.

42. Anderson AM, Munoz-Moreno JA, McClernon DR, Ellis RJ, Cookson D, Clifford DB, Collier AC, Gelman BB, Marra CM, McArthur JC, et al. Prevalence and correlates of persistent HIV-1 RNA in cerebrospinal fluid during antiretroviral therapy. J Infect Dis. 2017;215(1):105-13.

43. Havlir DV, Strain MC, Clerici M, Ignacio C, Trabattoni D, Ferrante P, Wong JK. Productive infection maintains a dynamic steady state of residual viremia in human immunodeficiency virus type 1-infected persons treated with suppressive antiretroviral therapy for five years. J Virol. 2003;77(20):11212-9.

44. Ramratnam B, Ribeiro R, He T, Chung C, Simon V, Vanderhoeven J, Hurley A, Zhang L, Perelson AS, Ho DD, et al. Intensification of antiretroviral therapy accelerates the decay of the HIV-1 latent reservoir and decreases, but does not eliminate, ongoing virus replication. J Acquir Immune Defic Syndr. 2004;35(1):33-7.

45. Dinoso JB, Kim SA, Wiegand AM, Palmer SE, Gange SJ, Cranmer L, O'Shea A, Callender M, Spivak A, Brennan T, et al. Treatment intensification does not reduce residual HIV-1 viremia in patients on highly active antiretroviral therapy. PNAS. 2009;106:9403-8.

46. Gandhi RT, Zheng L, Bosch RJ, Chan ES, Margolis DM, Read S, Kallungal B, Palmer S, Medvik K, Lederman MM, et al. The effect of raltegravir intensification on low-level residual viremia in HIV-infected patients on antiretroviral therapy: a randomized controlled trial. PLoS Med. 2010;7(8):e1000321.

47. Hatano H, Hayes TL, DahI V, Sinclair E, Lee TH, Hoh R, Lampiris H, Hunt PW, Palmer S, McCune JM, et al. A randomized, controlled trial of raltegravir intensification in antiretroviral-treated, HIV-infected patients with a suboptimal CD4+ T cell response. J Infect Dis. 2011;203(7):960-8.

48. Markowitz M, Evering TH, Garmon D, Caskey M, La Mar M, Rodriguez K, Sahi V, Palmer S, Prada N, Mohri H. A randomized open-label study of 3versus 5-drug combination antiretroviral therapy in newly HIV-1-infected individuals. J Acquir Immune Defic Syndr. 2014;66(2):140-7.

49. McMahon D, Jones J, Wiegand A, Gange SJ, Kearney M, Palmer S, McNulty S, Metcalf JA, Acosta E, Rehm C, et al. Short-course raltegravir intensification does not reduce persistent low-level viremia in patients with HIV-1 suppression during receipt of combination antiretroviral therapy. Clin Infect Dis. 2010;50(6):912-9.

50. Buzon MJ, Massanella M, Llibre JM, Esteve A, DahI V, Puertas MC, Gatell JM, Domingo P, Paredes R, Sharkey M, et al. HIV-1 replication and immune dynamics are affected by raltegravir intensification of HAART-suppressed subjects. Nat Med. 2010;16(4):460-5.

51. YukI SA, Shergill AK, McQuaid K, Gianella S, Lampiris H, Hare CB, Pandori $M$, Sinclair $E$, Gunthard HF, Fischer $M$, et al. Effect of raltegravir-containing intensification on HIV burden and T-cell activation in multiple gut sites of HIV-positive adults on suppressive antiretroviral therapy. AIDS. 2010;24(16):2451.

52. Archin NM, Liberty AL, Kashuba AD, Choudhary SK, Kuruc JD, Crooks AM, Parker DC, Anderson EM, Kearney MF, Strain MC, et al. Administration of vorinostat disrupts HIV-1 latency in patients on antiretroviral therapy. Nature. 2012;487(7408):482-5.

53. Elliott JH, Wightman F, Solomon A, Ghneim K, Ahlers J, Cameron MJ, Smith MZ, Spelman T, McMahon J, Velayudham P, et al. Activation of HIV transcription with short-course vorinostat in HIV-infected patients on suppressive antiretroviral therapy. PLoS Pathog. 2014;10(10):e1004473.

54. Rasmussen TA, Tolstrup M, Brinkmann CR, Olesen R, Erikstrup C, Solomon A, Winckelmann A, Palmer S, Dinarello C, Buzon M, et al. Panobinostat, a histone deacetylase inhibitor, for latent-virus reactivation in HIV-infected patients on suppressive antiretroviral therapy: a phase 1/2, single group, clinical trial. The Lancet HIV. 2014;1(1):e13-21.

55. Sogaard OS, Graversen ME, Leth S, Olesen R, Brinkmann CR, Nissen SK, Kjaer AS, Schleimann MH, Denton PW, Hey-Cunningham WJ, et al. The depsipeptide romidepsin reverses HIV-1 latency in vivo. PLoS Pathog. 2015;11(9):e1005142.

56. Xing S, Bullen CK, Shroff NS, Shan L, Yang HC, Manucci JL, Bhat S, Zhang $\mathrm{H}$, Margolick JB, Quinn TC, et al. Disulfiram reactivates latent HIV-1 in a $\mathrm{Bcl}$-2-transduced primary CD4+ T cell model without inducing global T cell activation. J Virol. 2011;85(12):6060-4.

57. Elliott JH, McMahon JH, Chang CC, Lee SA, Hartogensis W, Bumpus N, Savic R, Roney J, Hoh R, Solomon A, et al. Short-term administration of 
disulfiram for reversal of latent HIV infection: a phase 2 dose-escalation study. The Lancet HIV. 2015;2(12):e520-9.

58. Spivak AM, Andrade A, Eisele E, Hoh R, Bacchetti P, Bumpus NN, Emad F, Buckheit R 3rd, McCance-Katz EF, Lai J, et al. A pilot study assessing the safety and latency-reversing activity of disulfiram in HIV-1-infected adults on antiretroviral therapy. Clin Infect Dis. 2014;58(6):883-90.

59. Rasmussen TA, Anderson JL, Wightman F, Lewin SR. Cancer therapies in HIV cure research. Curr Opin HIV AIDS. 2017;12(1):96-104.

60. Fromentin R, Bakeman W, Lawani MB, Khoury G, Hartogensis W, DaFonseca S, Killian M, Epling L, Hoh R, Sinclair E, et al. CD4+ T cells expressing PD-1, TIGIT and LAG-3 contribute to HIV persistence during ART. PLOS Pathog. 2016;12(7):e1005761.

61. Trautmann L, Janbazian L, Chomont N, Said EA, Gimmig S, Bessette B, Boulassel MR, Delwart E, Sepulveda H, Balderas RS, et al. Upregulation of PD-1 expression on HIV-specific CD8+ T cells leads to reversible immune dysfunction. Nat Med. 2006;12(10):1198-202.

62. Gay CL, Bosch RJ, Ritz J, Hataye JM, Aga E, Tressler RL, Mason SW, Hwang CK, Grasela DM, Ray N, et al. Clinical trial of the anti-PD-L1 antibody BMS-936559 in HIV-1 infected participants on suppressive antiretroviral therapy. J Infect Dis. 2017;215(11):1725-33.

63. Wightman F, Solomon A, Kumar SS, Urriola N, Gallagher K, Hiener B, Palmer S, McNeil C, Garsia R, Lewin SR. Effect of ipilimumab on the HIV reservoir in an HIV-infected individual with metastatic melanoma. AIDS. 2015;29(4):504-6.

64. Rasmussen TA, McMahon J, Chang JJ, Symons J, Roche M, Dantanarayana A, Okoye A, Hiener B, Palmer S, Lee WS, et al. Impact of alemtuzumab on HIV persistence in an HIV-infected individual on antiretroviral therapy with Sezary syndrome. AIDS. 2017;31(13):1839-45.

65. Gratton S, Cheynier R, Dumaurier MJ, Oksenhendler E, Wain-Hobson $S$. Highly restricted spread of HIV-1 and multiply infected cells within splenic germinal centers. Proc Natl Acad Sci USA. 2000;97(26):14566-71.

66. Jung A, Maier R, Vartanian JP, Bocharov G, Jung V, Fischer U, Meese E, Wain-Hobson S, Meyerhans A. Recombination: multiply infected spleen cells in HIV patients. Nature. 2002;418(6894):144.

67. Rothenberger MK, Keele BF, Wietgrefe SW, Fletcher CV, Beilman GJ, Chipman JG, Khoruts A, Estes JD, Anderson J, Callisto SP, et al. Large number of rebounding/founder HIV variants emerge from multifocal infection in lymphatic tissues after treatment interruption. Proc Natl Acad Sci USA. 2015;112(10):E1126-34.

68. Veazey RS, DeMaria M, Chalifoux LV, Shvetz DE, Pauley DR, Knight HL, Rosenzweig M, Johnson RP, Desrosiers RC, Lackner AA. Gastrointestinal tract as a major site of $C D 4+T$ cell depletion and viral replication in SIV infection. Science. 1998;280(5362):427-31.

69. Barton K, Hiener B, Winckelmann A, Rasmussen TA, Shao W, Byth K, Lanfear R, Solomon A, McMahon J, Harrington S, et al. Broad activation of latent HIV-1 in vivo. Nat Commun. 2016;7:12731.

70. Dai J, Agosto LM, Baytop C, Yu JJ, Pace MJ, Liszewski MK, O'Doherty U. Human immunodeficiency virus integrates directly into naive resting CD4+ T cells but enters naive cells less efficiently than memory cells. J Virol. 2009;83(9):4528-37.

71. Eckstein DA, Penn ML, Korin YD, Scripture-Adams DD, Zack JA, Kreisberg JF, Roederer M, Sherman MP, Chin PS, Goldsmith MA. HIV-1 actively replicates in naive $\mathrm{CD} 4(+) \mathrm{T}$ cells residing within human lymphoid tissues. Immunity. 2001;15(4):671-82.
72. Wightman F, Solomon A, Khoury G, Green JA, Gray L, Gorry PR, Ho YS, Saksena NK, Hoy J, Crowe SM, et al. Both CD31(+) and CD31 naive CD4(+) T cells are persistent HIV type 1-infected reservoirs in individuals receiving antiretroviral therapy. J Infect Dis. 2010;202(11):1738-48.

73. Carter CC, Onafuwa-Nuga A, McNamara LA, Riddell J, Bixby D, Savona MR, Collins KL. HIV-1 infects multipotent progenitor cells causing cell death and establishing latent cellular reservoirs. Nat Med. 2010;16(4):446-51.

74. Durand CM, Ghiaur G, Siliciano JD, Rabi SA, Eisele EE, Salgado M, Shan L, Lai JF, Zhang H, Margolick J, et al. HIV-1 DNA is detected in bone marrow populations containing CD4+ T cells but is not found in purified CD34+ hematopoietic progenitor cells in most patients on antiretroviral therapy. J Infect Dis. 2012;205(6):1014-8.

75. Winckelmann A, Barton K, Hiener B, Schlub TE, Shao W, Rasmussen TA, Ostergaard L, Sogaard OS, Tolstrup M, Palmer S. Romidepsin-induced HIV-1 viremia during effective ART contains identical viral sequences with few deleterious mutations. AIDS. 2017;31(6):771-9.

76. Siliciano JD, Siliciano RF. Enhanced culture assay for detection and quantitation of latently infected, resting CD4+ T-cells carrying replicationcompetent virus in HIV-1-infected individuals. In: Zhu T, editor. Human retrovirus protocols: virology and molecular biology. Totowa: Humana Press; 2005. p. 3-15

77. Procopio FA, Fromentin R, Kulpa DA, Brehm JH, Bebin A-G, Strain MC, Richman DD, O'Doherty U, Palmer S, Hecht FM, et al. A novel assay to measure the magnitude of the inducible viral reservoir in HIV-infected individuals. EBioMedicine. 2015;2(8):874-83.

78. Butler SL, Hansen MST, Bushman FD. A quantitative assay for HIV DNA integration in vivo. Nat Med. 2001;7(5):631-4.

79. Liszewski MK, Yu JJ, O'Doherty U. Detecting HIV-1 integration by repetitive-sampling Alu-gag PCR. Methods. 2009;47(4):254-60.

80. Vandergeeten C, Fromentin R, Merlini E, Lawani MB, DaFonseca S, Bakeman W, McNulty A, Ramgopal M, Michael N, Kim JH, et al. Cross-clade ultrasensitive PCR-based assays to measure HIV persistence in largecohort studies. J Virol. 2014;88(21):12385-96.

81. Elliott JH, Wightman F, Solomon A, Ghneim K, Ahlers J, Cameron MJ, Smith MZ, Spelman T, McMahon J, Velayudham P, et al. Activation of HIV transcription with short-course vorinostat in HIV-infected patients on suppressive antiretroviral therapy. PLoS Pathog. 2014;10(11):e1004473.

82. Kiselinova M, Pasternak AO, De Spiegelaere W, Vogelaers D, Berkhout B, Vandekerckhove L. Comparison of droplet digital pcr and seminested real-time PCR for quantification of cell-associated HIV-1 RNA. PLoS ONE. 2014;9(1):e85999.

83. Hong F, Aga E, Cillo AR, Yates AL, Besson G, Fyne E, Koontz DL, Jennings C, Zheng L, Mellors JW. Novel assays for measurement of total cell-associated HIV-1 DNA and RNA. J Clin Microbiol. 2016;54(4):902-11.

84. Lorenzo-Redondo R, Fryer HR, Bedford T, Kim EY, Archer J, Pond SLK, Chung YS, Penugonda S, Chipman J, Fletcher CV, et al. Persistent HIV-1 replication maintains the tissue reservoir during therapy. Nature. 2016;530(7588):51-6.

\section{Submit your next manuscript to BioMed Central and we will help you at every step:}

- We accept pre-submission inquiries

- Our selector tool helps you to find the most relevant journal

- We provide round the clock customer support

- Convenient online submission

- Thorough peer review

- Inclusion in PubMed and all major indexing services

- Maximum visibility for your research

Submit your manuscript at www.biomedcentral.com/submit
BioMed Central 